\title{
A geographic information system for the study of past epidemics: The 1705 epidemic in Martigues (Bouches-du-Rhône, France)
}

\author{
Isabelle Séguy \\ Institut National d'Etudes Démographiques, Paris, and
}

CEPAM (Cultures et Environnements - Préhistoire, Antiquité, Moyen Age, UMR 7264, Centre National de la Recherche Scientifique-Université de Nice-Sophia-Antipolis), Nice seguy@ined.fr

Nicolas Bernigaud

CEPAM (UMR 7264, Centre National de la Recherche Scientifique-Université de NiceSophia-Antipolis), Nice, and Institut National d'Etudes Démographiques, Paris

Arnaud Bringé

Institut National d'Etudes Démographiques, Paris

Michel Signoli

ADES (Anthropologie bio-culturelle, Droit, Ethique et Santé, UMR 7268, Centre National de la Recherche Scientifique-Université de la Méditerranée-

Etablissement Français du Sang-Ministère de la Culture), Marseille

\section{Stéfan Tzortzis}

ADES (UMR 7268, Centre National de la Recherche Scientifique-Université de la Méditerranée-Etablissement Français du Sang-Ministère de la Culture), Marseille, and Service Régional de l'Archéologie de Provence-Alpes-Côte d'Azur, Aix-en-Provence

\begin{abstract}
At the beginning of the 18th century, the Provence region was hit by several severe epidemics whose causes are still not clearly understood. To draw up epidemic profiles and to identify the pathogenic agents concerned, we constituted a large onomastic database and built a geographic information system for Martigues, a medium-sized community in the south of France. The cross-linking of epidemiological, spatial and demographical data allows us to propose a new diagnosis for the epidemic which reached Martigues in the autumn of 1705.
\end{abstract}

Keywords: GIS, reconstruction of the urban network, epidemics, dysentery, Q fever, measles, smallpox, whooping cough.

\section{Résumé}

Au début du XV TII siècle, la Provence a subi plusieurs crises épidémiques dont les causes ne sont pas toujours bien connues. Pour établir les profils épidémiques et tenter d'identifier les agents pathogènes, nous avons constitué une base de données nominative et crée un système d'information géographique pour Martigues, une ville moyenne du sud de la France. Le croisement de données épidémiologiques, spatiales et démographiques nous permet de proposer un nowveau diagnostic pour l'épidémie qui a sévi à Martigues en 1705.

Mots-clés : SIG, reconstitution de la trame urbaine, épidémies, dysenterie, fièrre $Q$, rougeole, variole, coqueluche. 


\section{Introduction}

The population dynamics of the 17th and 18th centuries were influenced by a number of severe epidemics. Their intensity, nature, and impact were very variable, prompting different adaptive responses, and producing demographic consequences that varied in extent. Our study involves a multidisciplinary approach, based on data, methods, and tools from anthropology, archaeology, history, epidemiology, demography, and spatial geography. The study of past diseases is of demographic and historical interest, but it also informs us about the spread of infectious diseases for which no effective medical treatment existed at the time.

Our study uses a geographic information system (GIS), a computer tool to link spatial information with historical demographic data. The GIS offers a double advantage: first, it provides a simple and rapid means to create thematic maps via the associated databases, called attribute tables (only this first capability was used in the present study); second, the GIS can also be used for spatial and statistical analyses. Studying spatial patterns with micro-level data opens the way to new approaches in historical demography and paleoepidemiology. Here, the objective is to analyse the spatial and demographic patterns of a mortality crisis that affected a medium-sized city of southern France at the beginning of the 18th century - the 1705 epidemic, for which we have no records and no description of the symptoms that would permit a retrodiagnosis.

Until now, historical uses of GIS focused on the 19th century, because data for that period are various, readily accessible, and precise. Contemporary cadastral maps and textual data are also widely available (Knowles 2000; Gregory 2003). This approach has been used, for example, to link national census data with the changing administrative boundaries used to publish them (Gregory 2003, 2005; Knowles 2005), then to analyse population change in time and space (Gregory and Hell 2005; Ekamper 2010). A few studies concern mortality (Orford et al. 2002; Gregory 2008), again for the 19th century. Our challenge was to build a GIS for an earlier period (18th century) when cadastral maps did not exist and — beyond demonstrating that this is possible — to show what can be achieved (at the very least) using GIS to further the study of past epidemics.

Mapping the diffusion of an epidemic is nothing new. One-and-a-half centuries ago in London, Dr. John Snow located the polluted well which was at the origin of the 1854 cholera epidemic. Nowadays, health institutes use GIS to identify potential reservoirs (contaminated animals) and follow the spread of infectious diseases such as malaria, cholera, Lyme disease, and plague, which is still endemic in some parts of the world. The use of these new technologies for epidemiological surveillance is quite recent, however, with most applications dating back less than fifteen years (WHO 1999). Studies using GIS to follow past epidemics are very scarce (Yu and Christakos 2006; Tuckel et al. 2006), especially those focusing on periods before the 19th century, when no records of causes of death were generally available.

Despite the limits of 18th-century data, the study of past epidemics calls for an analysis in both time and space. Although a time-consuming procedure, the creation of a specific GIS allows us to study and model the contamination and diffusion pathways of epidemics, ${ }^{1}$ to process large volumes of data, to map them easily and to analyse them statistically. It is ideally suited for analysing the abundant historical sources at our disposal. Initial small-scale and large-scale tests were conducted; first on Provence and Languedoc, a vast region engaged in intensive exchanges with neighbouring provinces and the Mediterranean, and affected by the last French plague - the "Plague of Marseilles" between 1720 and 1722 (Séguy et al. 2005a); second, on the enclosed space of Martigues city, to highlight the modes of diffusion of the different pathogenic agents (Séguy et al. 2005b).

This paper describes the creation of a specific historical GIS to study the epidemic of 1705 in Martigues. The article is divided into three parts: the first part describes the city of Martigues at the beginning of the 18th century and the data we used; the second explains how we draw, digitalize, vectorize, and georeference the data to create the GIS, and how we link nominative data to produce a database associated with spatial information, and discusses the biases and difficulties encountered; and the third part examines the demographic and spatial patterns (here, by geovizualisation only) of the epidemic, whose pathogenic causes are not recorded, and proposes a reinterpretation of the disease.

1. It also allows us various sociodemographical and environmental studies that will be not developed here. 


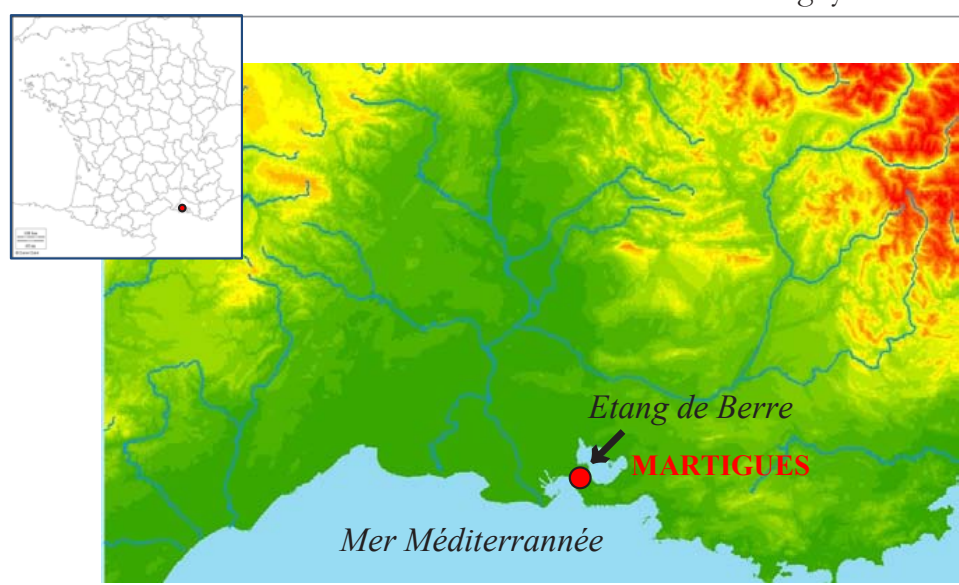

Figure 1. Location of the town of Martigues in southeastern France.

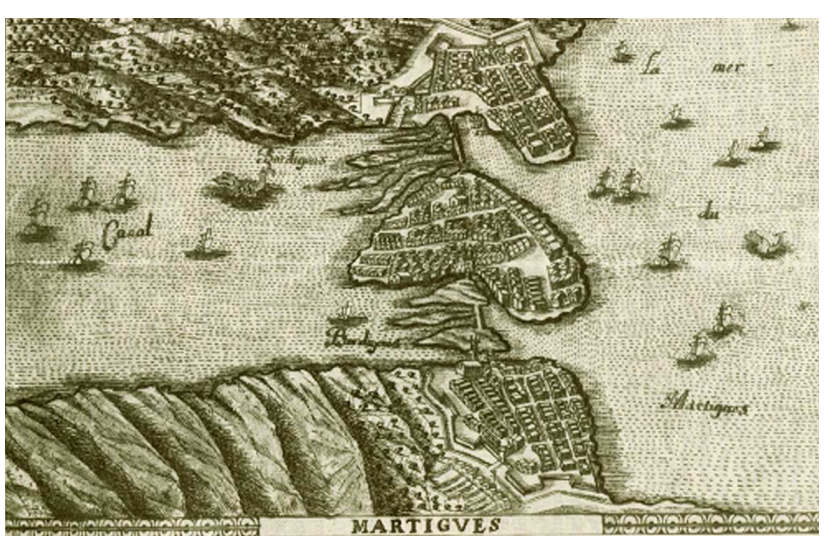

Figure 2. Map of the three parishes of Martigues: Map of the seaports, appended to the map of the Provence coastline drawn by Maretz (1633); Bibliothèque Nationale de France (Ge DD 2987).

\section{Place and data}

\section{Martigues, an enclosed city on the Mediterranean coast}

In the Modern era, Martigues was an important city of Western Provence, which controlled the entrance from the Mediterranean Sea to the marshy Etang de Berre via the Caronte channel (Fig. 1 and 2). Located halfway between Marseilles, Aix, and Arles, it was a maritime city, both by its location and by its main activities of trade and fishing.

An original feature of the city was its division into three districts, attested from the 13th century, each corresponding to an ancient community: Jonquières district, on the south shore of the channel, was established by the Benedictine abbey of Montmajour; L'Ile (the "Island") district, on the channel, was founded by the Comte de Provence, Raymond Béranger; and Ferrières district, in the North, was a "ville nouvelle" (new town), a creation of the archbishop of Arles (Fig. 2). These originally independent communities were united in 1581 under the name of Martigues.

Each district maintained the statutory components of an independent community: its own parish church, chapels, hospital, ovens, and mills. At the beginning of the 17th century, the line of walls, which is very clear on Figure 2, still determined the topography of the city, although numerous houses had already been built along the walls, near the city gates. Bridges or drawbridges provided a passage from one neighbourhood to another.

\section{A composite community, on the eve of its demographic decline}

The city of Martigues peaked economically and demographically in the 17th century. At the beginning of the 18th century, its population was still large; Paoli (1971) estimates that the city and its lands held about 10,000 inhabitants, of whom 7,200 lived inside the city. However, from the early 18th century, the city appears to have entered a phase of decline. The 1702 census counts a population of 5,602 inhabitants within the city walls, to which Paoli (1971: 14) adds a further 2,000 inhabitants living on the city's land. The upheavals marking the end of Louis XIV's reign, the War of Succession in Spain (1701-1713), demographic crises and epidemics, famines, and climatic catastrophes further contributed to the city's population decline in the first quarter of the 18th century. In 1716, the city counted no more than 8,000 inhabitants (Paoli 1791: 14; and 5,888 according to the Etat du nombre des familles et des personnes de chaque lieu de Provence). ${ }^{2}$ During the plague of 1720, more than 2,000 persons died.

\section{Nominative data}

Parish registers and population censuses (such lists of inhabitants were uncommon in the early 18th century) are the best sources for population studies. They allow us to link individuals, families and households, and they define the social and family network of the city. They also provide socioeconomic and spatial information (such as the precise location of each household).

2. Archives of Intendant Lebret, Bibliothèque nationale, ms fr 8908. Document published by Jean-Noël Biraben (1975: 339 aud.). 


\section{Parish registers ${ }^{3}$}

We also used parish registers to build a population database that provides the following information for each inhabitant: surname, first name, sex, age at death, biological or marital kinship ties, occupation, origin, address, and if $s /$ he died of one of the diseases under study.

The parish registers of the three urban parishes were analysed from 1701 to 1725 to reconstruct the movements of the urban population between the 1702 Census and the beginning of the plague (Signoli 1998), and to follow the individual destinies of Martigues' inhabitants during those difficult years.

We paid special attention to the burial registers which are very important for epidemiological analysis. The records are continuous, despite the severe mortality crisis suffered by the population (including the plague in 1720-21). They provide the surname, first name, sex, age at death, date and place of burial, parents' or spouse's identity, occupation, and various other details (e.g., consanguineous parentage). The cause of death is almost never mentioned on the burial records, except during plague epidemics.

We also counted the annual baptisms, marriages, and burials in order to reconstitute long-term population change and observe demographic crises within the general trend (Fig. 5).

\section{A city census in $1702^{4}$}

Following the re-establishment of a poll tax or "capitation" in 1701, a General Census of Martigues' population was undertaken in January 1702, ordered by the Intendant of Provence. This new direct tax was imposed upon both nobles and commoners.

Each inhabitant was recorded, district by district, street by street, home by home, family by family. This census also recorded the name of the homeowner; his identity and age, the occupation of the head of the family; the identity and age of his spouse; the number of children, their individual names and ages, as well as their occupation, if any. Members of the parents' extended family and domestic staff living with the family were also noted. Data on the household were sometimes supplemented by information on persons' geographical origin, social condition, or state of indigence (e.g., "beggar without bread or worldly goods").

This document, established for tax purposes, contained some omissions; some houses outside the city walls seem to have been omitted, and three pages of the Ile district are missing. In addition, as this type of source only counts the de jure population and not the de facto population, certain inhabitants may be omitted.

\section{"Cartographic" data}

Studying spatial patterns with micro-level data requires small-scale spatial information such as that found on 19th-century cadastral maps. But for periods before these documents came into existence, micro-scale information can be found in written documents such as land registers. Converting non-cartographic information into cartographic data is a real challenge; it is difficult and time-consuming, because the entire urban infrastructure must first be reconstructed, working house by house.

To digitize, vectorize, and georeference the plots described on the land registers, we used the Napoleonic land register. This, and the study of ancient detailed maps of the city drawn between the 16th and the 18th century, allowed us to remove the anachronistic buildings and modify the plots drawn in the Napoleonic land register. The plots in the centre of the town remained quite stable from 1716 to 1817 (mainly only divided or merged), so it was possible to link the cadastral sections of 1817 to the properties described in the land register.

As the land register provides information on owners and not on the occupants, we had to link each inhabitant of Martigues to his/her house, following the indications of both the census and the land registers.

\section{Land registers (1716) ${ }^{5}$}

The city of Martigues was recorded in cadastral registers several times from the 15th century, to establish the base of direct taxation. For the period under study, only one land register was used, that of 1716, which follows that of 1580, produced soon after the act of union of 1584. Any intermediate registers have been lost.

3. Municipal archives of Martigues, GG 14 à 18 : L’Ile ; GG 30 à 34 : Jonquières; GG 46 à 48 : Ferrières.

4. Municipal archives of Martigues, CC 390.

5. Municipal archives of Martigues, CC 360-362. 
In fact, these documents are cadastral reports (bâtardeaux de cadastre) updated for the collection of the tax. Much like a modern land register, these fiscal documents establish the nature, surface area, and value of land (built and unbuilt) belonging to the community. Lists of ownership were established street by street. They specify the surname, first name and status of the owners and describe the houses in relation to their neighbours, thus allowing us to locate them on the city map.

\title{
Iconographic documents
}

For the period before the 19th century, in the absence of maps associated with the land registers, we used city maps that were drawn between the 16th and 18th centuries. These documents, variable in their accuracy and detail, allowed us to determine the spatial organization of the three districts and the plan of the old city. We specifically considered the map of Martigues attached to the general map of the coastline of Provence, drawn in 1633 by Jacques Maretz, during the detailed inspection of the French coast commissioned by Richelieu (Fig. 2).

\section{The "Napoleonic" land register"}

Accurate and small-scale cadastral maps were not produced in France until the beginning of the 19th century, when it was necessary to draw the boundaries of the "communes," the new micro-level administrative divisions created in 1792. Napoleon's official instructions specified how to establish the land register, and most French "communes" produced their own register between 1807 and 1833. The maps of the plots were drawn up in association with the written sources (État des sections). For every numbered plot on the cadastral map, the Etat des sections indicates the nature, the area and the value of the plot and the name and the occupation of the land owner. The "Napoleonic" land register of Martigues, established in this way, dates from $1817 .^{7}$

As these cadastral documents were produced with good topographical precision, they can readily be used in a GIS application.

\section{Methods}

\section{A GIS for the city of Martigues at the beginning of the 18th century}

\author{
Spatialization of descriptive data and reconstruction of the cadastral map of 1716
}

The first step was to transform descriptive data into spatial information compatible with mapping software. From the descriptions of the other properties adjacent to each house, as they appear in the land registers of 1716 (Fig. 3, left), we positioned each dwelling (horizontally and vertically) in the urban plan of the three parishes, building on the Napoleonic cadastral plans of the three urban districts of the city (Fig. 3, centre). This work is difficult, because the names of streets and public spaces changed over time, and the number of building storeys is not mentioned on the land registers. We therefore tried to reconstitute the urban topography of the 18th century, rebuilding the ramparts (from Jacques Maretz's map, 1633; Fig. 2), public spaces, and built and unbuilt plots according to the 1716 description. The division into plots and the regular alignment of houses, typical of "new towns" of the 12th to 13th centuries, was of great help for localizing subsequent property redistributions.

\section{Technical implementation of the GIS}

At the end of this first stage, we have a fairly accurate map of the city, but on paper (Fig. 3, right). The historic city centre changed little between the 18th and 19th centuries, so it was possible to use the 1817 maps. The cadastral sheets were first digitized, then geo-referenced, i.e., each image associated with a set of coordinates in Lambert II (extended; Fig. 5). Geo-referencing was performed using the current land register of Martigues (in Autocad DXF format) based on recent topographical surveys. Then, from the land register of 1817 (Fig. 3, centre), corrected and given Lambert II coordinates, a map of the houses was drawn in a polygonal vector layer. Each house drawn in vector mode is linked to its own information in the historical database (Fig. 4). The vector layers can be converted into three dimensions, making it possible to create an interactive map of the city.

6. Departmental Archives of Bouches-du-Rhône, 3 P 1260 à 1312, 1275 et 1276.

7. Departmental Archives of Bouches-du-Rhône, quotation 3P 1275-1276 for three districts within the city walls. 

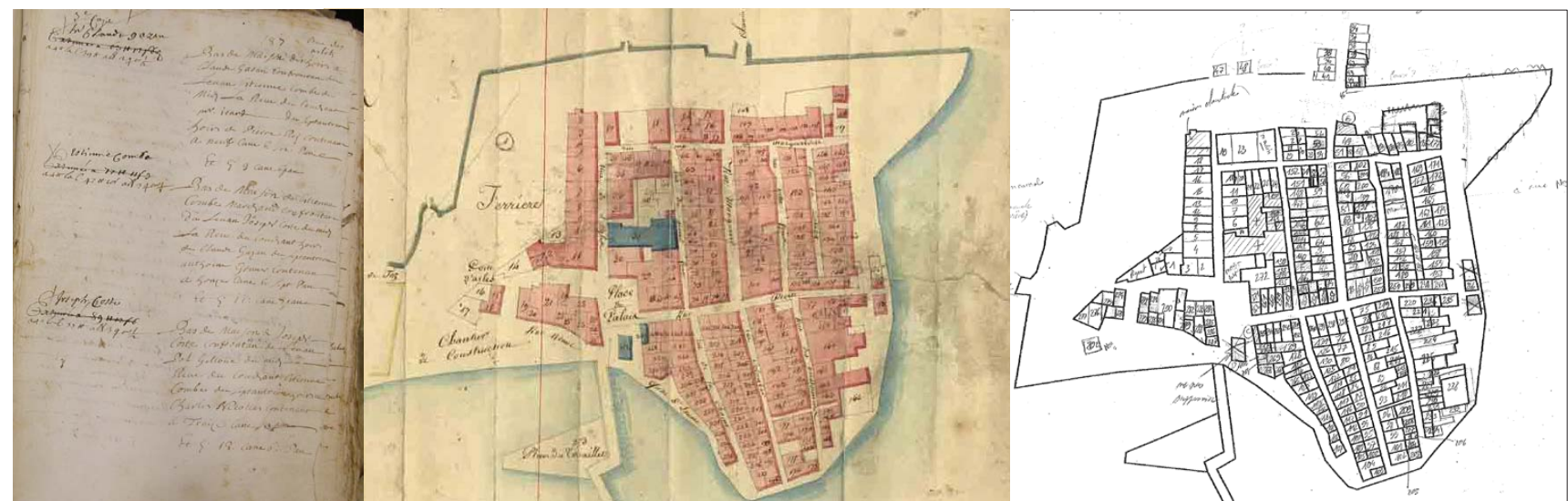

Figure 3. From the land register of 1716 to the reconstruction of the landscape of the 18th century (Ferrières district), based on the land register of 1817 and on the assumption of unchanging urban layout in the historical centre.

\section{Establishing a population register and associated database}

\section{Houses and Households in 1702}

After transforming the tax and descriptive information into cartographic data, we also needed to build an "address" file giving the exact location of each family. The 1702 census indicates who belongs to each house, so home-owning heads of household can be distinguished from tenants. The land registers of 1716 introduce an additional category, that of landlords who may or may not reside in Martigues. By cross-linking the two sources, it is possible to attribute a specific address to each family in 1702 and, assuming that residence remained unchanged for at least a few years, to localize the victims of the 1705 epidemic. For houses whose owners had changed between 1702 and 1716, we assumed that the route followed by the census recorder from house to house and from street to street was identical from one census to the next. In most cases, this enabled us to locate the families mentioned only in the 1702 census.

The Ferrières district, which serves here as an example, has an unfortunate peculiarity: the number of households per house was not specified in 1702. If we allocate one house to each household, we end up with too many houses in the district. So, based on the description of the largest houses in the 1716 land registers, we put two or three households into each, assuming that the size of the house and the number of storeys are correlated.

\section{Constituting a population register}

The census of 1702 is used to constitute a population database that evolves in response to the events that affect individuals throughout the observation period. Once the problem of surname spelling variations has been resolved, ${ }^{8}$ each person is identified by their surname, first name, sex, age, family or matrimonial links, occupation, origin and address in 1702. The file also specifies whether s/he is a homeowner or tenant, and if $\mathrm{s} /$ he was a victim of an epidemic that occurred during the first half of the 18th century.

While the parish registers record vital events (births, deaths, marriages, and migration out of the city) they do not track moves within the parish. The information on the residence of each inhabitant of Martigues becomes less accurate as the lapse of time since 1702 increases, because, while the land registers of 1716 authorized the recording of land transfers or changes of addresses by owners, they do not provide information on the mobility of tenants. Uncertainty about the location of some of them must be taken into account in the linkage operations and statistical analyses.

8. A group comparison function was used in the SAS software in order to calculate a penalty score for the comparison of two groups of characters based on spelling differences, variances of pattern (insertion, deletion, substitution, reversal) and positioning (beginning, middle or end of group). These scores were normalized by dividing by the number of characters. Below a certain threshold, similar names were considered as alternative spellings. A patronymic dictionary was thus created. This avoids counting the same person several times because of spelling variants found in different acts. 


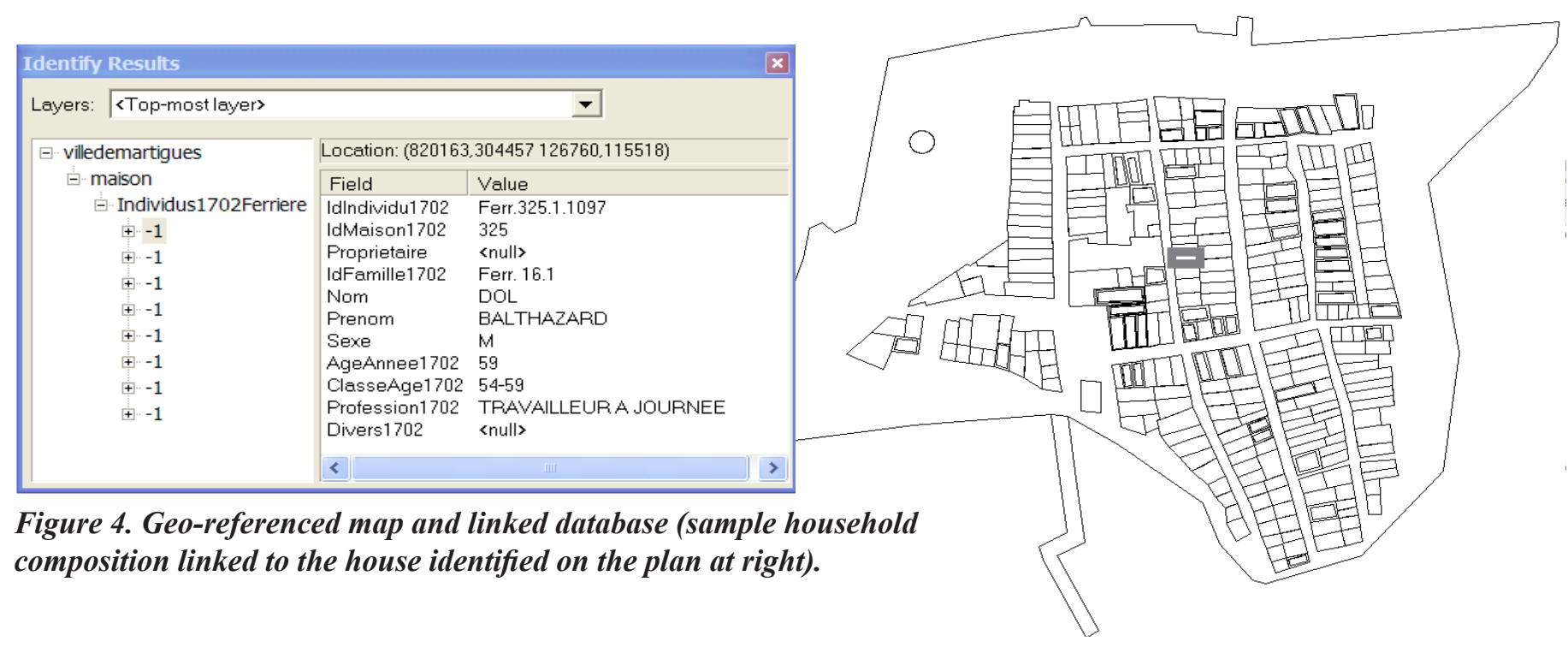

\section{Results and discussion}

\section{"Classical" analysis of the 1705 crisis in Martigues}

The annual counting of baptisms, marriages, and burials clearly shows the crisis of excess mortality that occurred in Martigues. In the first quarter of the 18th century, as in Provence and in France as a whole, the city suffered major demographic crises, some of which were echoed at a national and even European level. In times of crisis, burials increased while the number of baptisms and marriages decreased. Such a situation is characteristic of 1694, 1698-1700, 1705, 1709-10, and 1720-2 (Fig. 5). These crises are not all alike, with some resulting from natural disasters and situations of food shortage, exacerbated by a state of war, while others are exclusively due to the spread of highly pathogenic agents among vulnerable populations (Signoli et al. 2002; Séguy et al. 2007).

The 1705 demographic crisis has not been widely studied by historians, and its nature remains uncertain. Between 1705 and 1707, it was identified in many regions of France as dysentery caused by summer heat waves (Le Roy Ladurie 2004), or as an outbreak of smallpox (Goubert 1960; Lebrun 1971).

\section{A seasonal and selective epidemic}

In Martigues city, excess mortality appeared in the late summer and early autumn of 1705, and continued for several months up to the year-end (Fig. 6a, 7). It progressed parish by parish: Ferrières, located in the north, was reached first, followed by Ile and Jonquières. The excess mortality follows a pattern of person-to-person contamination, and does not appear to be linked to a particular place (e.g., a contaminated well) or animal vector. The presence of flocks of sheep on the land around Martigues exposed its inhabitants to the risk of Q fever, usually related to inhalation of dust contaminated with a highly infectious bacterium, Coxiella burnetii, transmitted by sheep and other mammals. The disease can also be contracted by contact with milk or contaminated wool, but no humanto-human transmission is known. All age groups are affected by this disease. The most common manifestation is flu-like symptoms but it can turn into a generally fatal pneumonia. Without antibiotic treatment, the chronic form of the disease is fatal. A study performed by H. Tissot-Dupont (2009) noted the importance of wind as a factor in its transmission (with an epidemiological peak two months later). These climatological data also characterize the environment of Martigues.

If the epidemic had been due to $Q$ fever, all the inhabitants would have been affected at the same time. As the epidemic spread from parish to parish (Fig. 6b), this diagnosis must be incorrect.

The age-at-death distribution shows that only young children were struck by the 1705 epidemic, and this is more visible if we compare the distribution of deaths by age at death during this epidemic and in "normal" times (non-epidemic years; Fig. 6c). About nine victims in ten were below 10 years old, of whom three-quarters were aged between 6 months and 6 years. This age group corresponds, from a biological point of view, to children who were no longer immunized by breast-feeding and had not yet acquired their own immunity. 


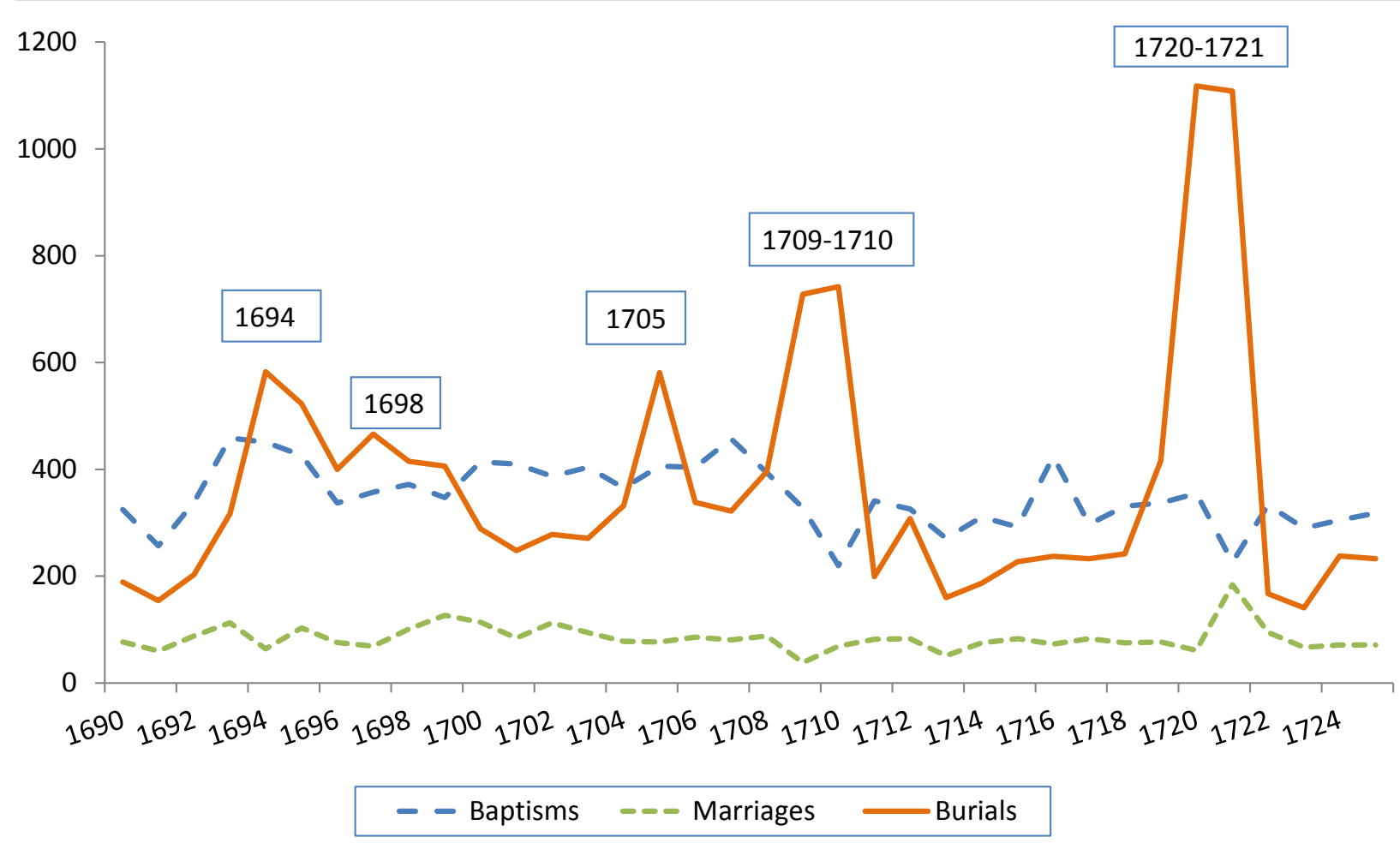

Figure 5. Annual number of baptisms, marriages, and burials in Martigues (1701-25). Note: The records are incomplete in the last years of the 17th century.

\section{Previous diagnoses}

In our opinion, these observations are not compatible with the diagnosis of dysentery proposed by E. Le Roy Ladurie. Only an infection by Shigella would affect children so exclusively, so selectively, and so seriously. However, it would not present different epidemic sources emerging over time, as was observed between the three districts of Martigues.

The information gathered in the first analysis (Séguy et al. 2005b) supports the hypothesis of eruptive fevers such as measles or smallpox. At the very end of the epidemic, the cyclical pattern of deaths - as well as the specific mortality of older victims (two 10-year-old children and one 80-year-old) with a family tie to one of the young victims - weigh in favour of the second diagnosis.

This diagnosis can be reconsidered by examining these data simultaneously in both spatial and temporal terms.

\section{Contribution of the GIS approach to the diagnosis of the 1705 epidemic: First results on the scale of the Ferrières district}

\section{New information brought to light by linking spatial and temporal information}

Thanks to the spatialization of data by the GIS system presented above, new information was brought to light on the spread of the epidemic in the Ferrières district. Being able to locate nine-tenths of the victims in their street, and over one in two in their homes, is sufficient to deduce that the whole district was affected and that there is no specific source of the epidemic. We nonetheless observe strong intrafamilial transmission: in many households, at least two deaths were reported, and in practically all cases, the deceased were children under 6 (Fig. 8a).

Moreover, the crossing of spatial data and the epidemic cycle, with an incubation period of ten to twelve days, has established a link between proximity and transmission of the pathogen. We have established a thematic map (Fig. 8b) indicating the dwellings where at least one death was recorded in the first, fourth, and seventh week, in order to take account of the time between infection, occurrence of symptoms, and ultimate death. Given that the source used is the register of deaths, children who recovered were not observed. Although the number of deaths is limited, we note some neighbourhood associations, suggesting direct contamination between children living in close proximity to each other, and a quick and fatal disease outcome. In terms of urban topography, we also observe that transmission was higher in the densely populated areas to the east. In the west, the presence of public buildings and churches, combined with a more open urban layout, substantially reduced the number of victims. 
Given the geographical proximity between the victims, we believe that a direct rather than indirect mode of contamination is involved.

To summarize these new data about the epidemic of Martigues in the autumn and early winter of 1705 obtained from the study of Ferrières district, we can say that it was an often fatal epidemic, that it targeted almost exclusively
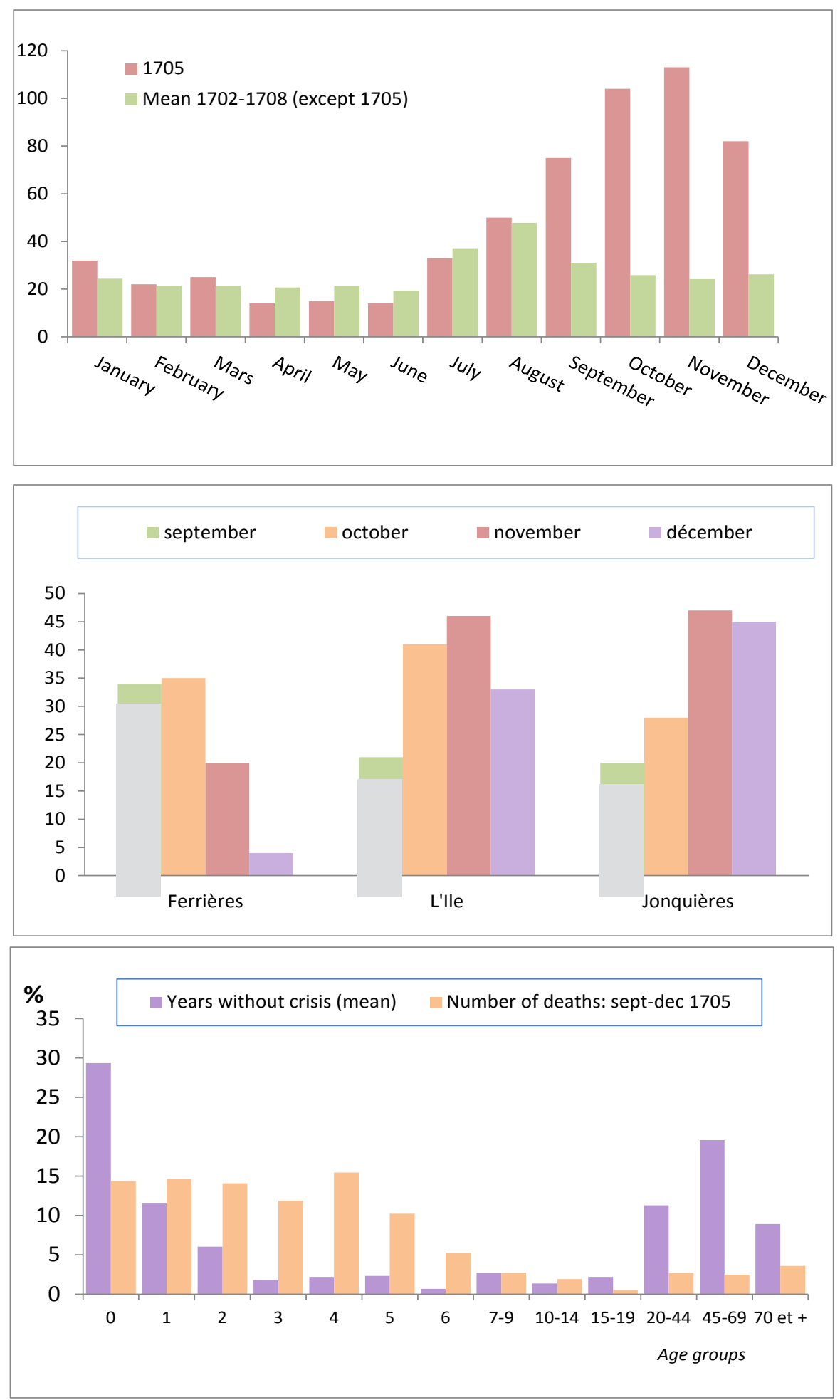

Figures 6a-c. Characterization of the epidemic: (a) seasonality of burials during the demographic crisis of 1705 compared with "normal" years (means recorded in 1702-4 and 1706-8); (b) spread of the epidemic through the three urban districts of Martigues; and (c) proportional distribution of deaths by age at death, in 1705 and during non-epidemic years (mean distribution). 


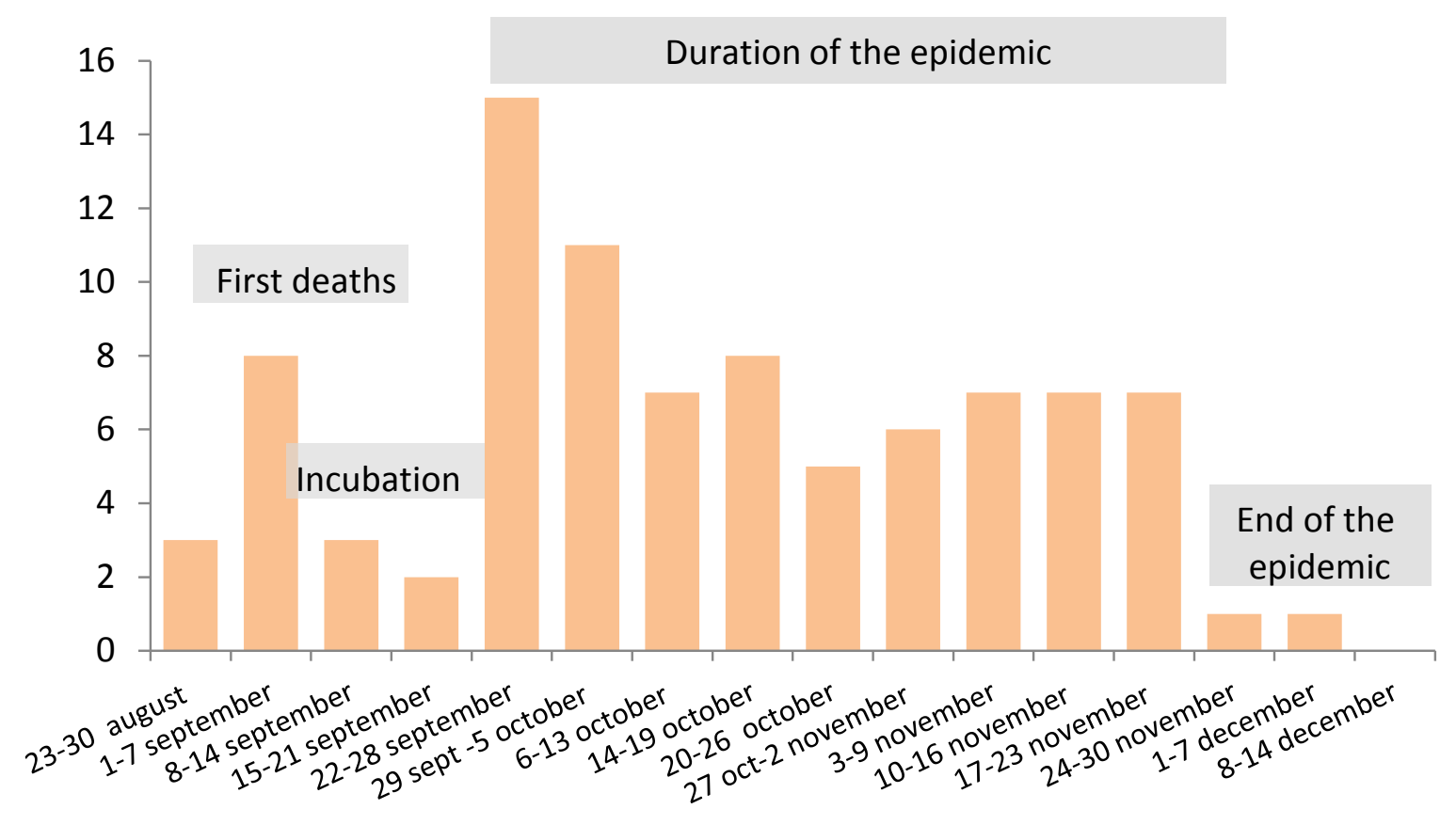

Figure 7. Number of deaths weekly at Ferrières, from August to December 1705.

children aged 6 months to 6 years, that the pathogen was highly contagious (intrafamilial transmission), and that it was present as an endemo-epidemic in this area. The epidemic spread regardless of the season, via a direct mode of transmission, and its virulence were enhanced by the weakened immune systems of the populations concerned and their unhealthy living conditions.

\section{A new diagnosis}

These various factors call into question our previous diagnosis of smallpox (Séguy et al. 2005b). Smallpox is an acute contagious disease caused by the variola virus. It is transmitted from person to person via infected aerosols and droplets from infected symptomatic people. Symptoms appear 12-14 days after infection (WHO website).

Even though smallpox had been present in Europe probably since medieval times, and was mentioned by Rhazes in his 10th-century medical treatise, which distinguished smallpox from measles (Darmon 1985: 24), it appears to have become endemic only in the 17th century (Albou 1995).

Historical studies on European smallpox epidemics in the early 18th century are scare, and are all based on mortality records with indications of the cause of death (Razzell 1977, 2007; Perrenoud 1979; Duncan et al. 1993, 1994). Most of them focus on the second half of the 18th century (after the first inoculation in England in 1721, and the discovery of a vaccine by Jenner in 1796; Darmon 1985; Skod 1996a, 1996b; Oldstone 1998; Eyler 2003), or on non-European contexts (Desjardins 1996, for Canada). So we do not have many points of comparison; the smallpox mortality rate was around 10\% during the 18th century, according to Darmon (1985: 59), consistent with what was observed in Martigues (6.2\%). But there is no concordance for seasonality; according to Perrenoud (1979: 473), sudden smallpox epidemics occurred during hot summers in Geneva and, according to Scott and Duncan (2001: 365), during low autumn rainfall in London. In Martigues, the epidemic occurred after a very hot summer, but in the autumn.

Another distinctive characteristic of smallpox is the fact that the disease mainly but not exclusively affected young people. According to Duvillard (1802, quoted by Darmon 1985: 61), at the end of the 18th century children under 10 years old accounted for $90.8 \%$ of smallpox mortality, those $10-19$ years old for $5.5 \%$, and adults (20 or more years old) for 3.7\%. Comparing the mortality by age and cause in Martigues (i.e., the difference between the age distribution of deaths observed during the four months of the 1705 epidemic and that observed in "normal" years as defined for Fig. 6a) with the mortality by age published by Duvillard (Fig. 9), the variola virus seems to be an unlikely culprit.

9. But until the mid-18th century and F. Boissier de Sauvage's work (1760), chicken pox and smallpox were confused (Shulman 2004: 165). 

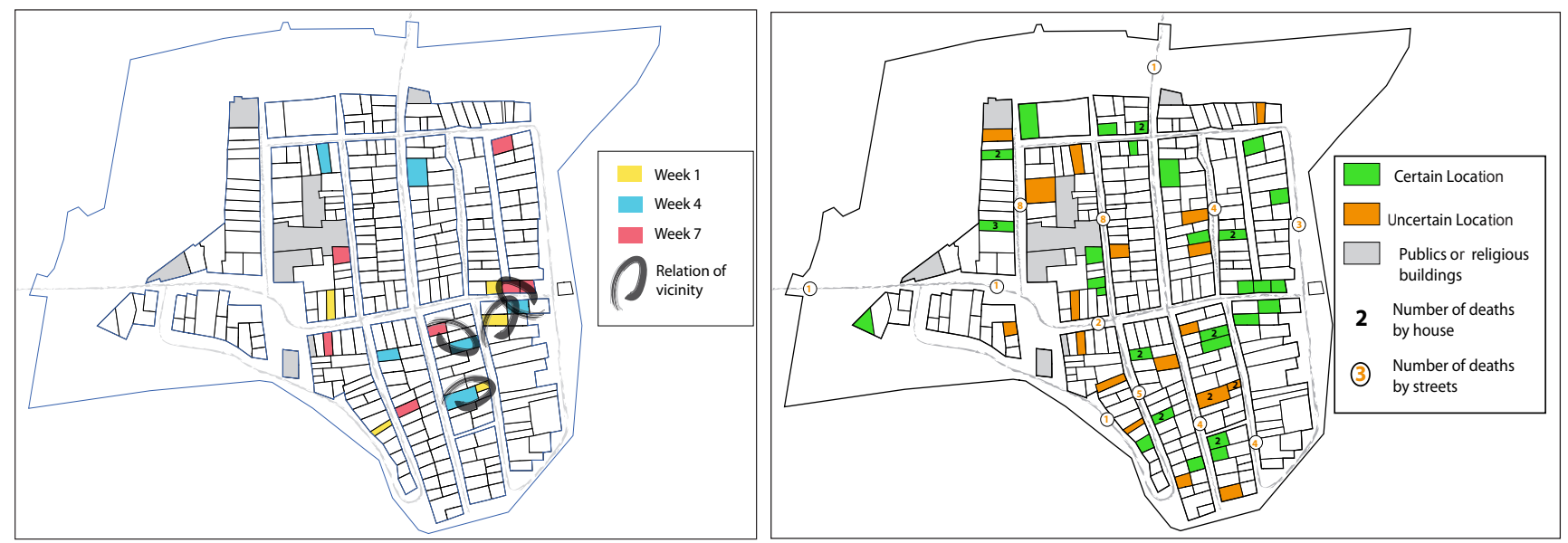

Figure 8a-b. Geolocalization of the victims: (a) location of families with one or more deaths during the epidemic, in their streets or, more precisely, in their homes (the numbers of deaths per house do not add up to the numbers of deaths per street); (b) relations of proximity, based on an average incubation period of ten to twelve days.

Other pathogenic agents can produce symptoms similar to the ones we noted-notably, the bacteria Bordetella pertussis, responsible for whooping cough, a respiratory disease that severely affects the poor and may lead to rapid death.

The first mention of a whooping cough epidemic in France dates from 1414, and the disease was first described medically by Baillou in Livre des Epidémies, 1574, published in 1640 by Thevart (Bouchut 1873: 526-7). It is transmitted only by direct infection and still affects children under three years of age, for whom it can be fatal (this was also noted by Baillou). Following an incubation period of 9-10 days, paroxysmal coughing ending in the characteristic whoop may occur (WHO website). During the entire modern period, whooping cough was present in endemo-epidemic form. It mainly affected children aged between 2 and 5 years, but could occur before age 1 if the infant did not have any maternal immunization (by breastfeeding). Without effective treatment, the disease can be fatal within a few days.

Duncan et al. $(1996,1998)$ note that the virulence of Bordetella pertussis is higher in case of malnutrition, which was widespread in Martigues from the end of the 17th century. They suggested that the population's susceptibility to whooping cough was governed by the wheat prices, themselves dependent on seasonal temperature variations. Other risks factors are highlighted, such as large family size, overcrowding, and low birth weight (Berman 1991; Duncan et al. 1996, 1998; Nielsen et al. 2001). Whooping cough was a major cause of infant death in the modern period, and still is today, with a re-emergence of the disease (WHO website; Guiso and Simondon 2001; Cherry 2003; Guiso 2007).
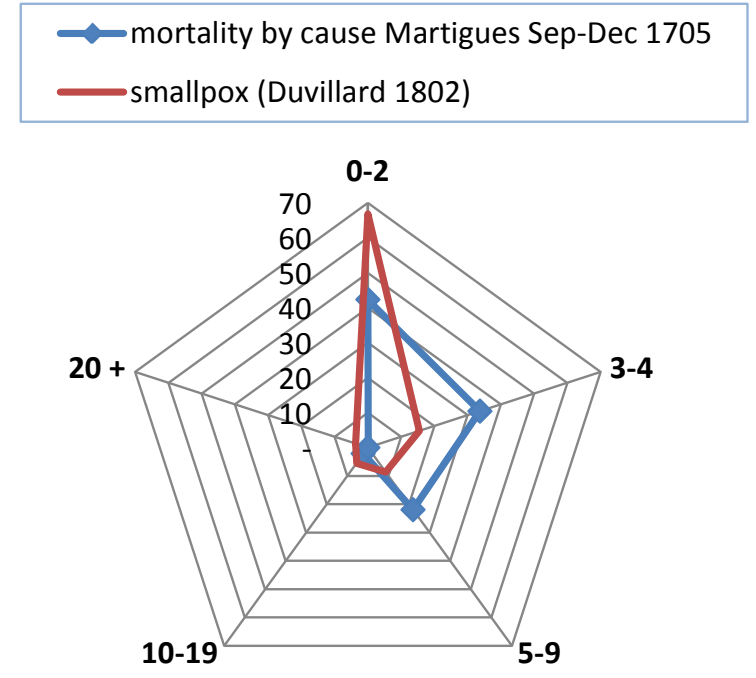

Figure 9. Comparison between smallpox mortality by age (Duvillard 1802) and that due to the pathogenic agent in Martigues. 
The illness occurs at any season of year, regardless of climate. All these factors make this diagnosis plausible, but they do not completely eliminate the hypothesis of measles, in particular because of the numerous recorded cases of intrafamilial transmission.

Measles is a highly contagious viral disease, which mostly affects children. It is transmitted via droplets from the nose, mouth, or throat of infected persons. In malnourished children and people with reduced immunity, measles can still cause serious complications today, including blindness, encephalitis, severe diarrhea, ear infection, and pneumonia (WHO website).

In the early 18th century, this disease was also endemo-epidemic in France. Like whooping cough, measles is a rash which primarily affects children above 6 months and can be rapidly fatal. Its incubation period is also very similar, around 10-12 days. Measles appears in a more severe form in the context of undernutrition; in this case, mortality is high and immediate. The disease is also particularly severe, and frequently fatal, when transmitted between brothers and sisters (Mazan et al. 2009; Mazan 2011; Burstrom et al. 1999; Goualde 2006: 141-2), as was the case in Ferrières district (cf. Fig. 8a). However, unlike whooping cough, it is transmitted both directly and indirectly (via objects) and is much more contagious; it is even more contagious than smallpox. It is also independent of climate and occurs throughout the year, although some authors note a preference for autumn (Duncan et al. 2001; Mazan 2011). Several authors mention a sex ratio unfavourable for girls (Mazan 2011: 51; Garenne 1994), but a sex imbalance is not observed in Martigues (51\% of the deaths concerned girls, $49 \%$ in boys).

The distribution of deaths by age during an epidemic of measles or of whooping cough could have been a discriminating element, but at this stage of our research, we have not found such data for any periods before vaccination. So, based on the observed data, the preferential diagnosis remains for an epidemic of whooping cough; however, it must be confirmed by analysis on the scale of the city and the surrounding villages as a whole.

\section{Conclusion}

The study presented here gives an example of how spatialized data can be usefully exploited by historical demographers. Before spatialization can be performed, the geographical area inhabited by the Modern Era populations must be reconstituted using a wide range of accurate and reliable cartographic and descriptive documents.

While onomastic databases are routinely used in historical demography, they have rarely been applied in the field of paleoepidemiology research. The results presented here show that parish registers contain much more information than suggested at first sight. However, when information is drawn from very different sources not initially intended for either demographic or medical research, but rather for tax or religious purposes, as is the case here, the identification of individuals is a very complex problem. At a time when the spelling of surnames was not fixed, and when familiar names and/or patronyms were commonly used for married women, record linkage is more complicated and a dictionary of spelling variants is needed (cf. note 8).

The use of textual data from tax documents to construct a map of a city and its territories is highly innovative. However, the integration of historical data into a geographic information system involves an initial process of interpretation whose assumptions and hypotheses must be specified. Geographical mobility, whether inside or outside the city walls of Martigues, remains an obstacle that cannot be ignored in the periods of interest to us. As in all monographic studies, the least mobile inhabitants are those for whom we have most information; working with a population of homeowners represents a major advantage in any sociodemographic or epidemiological approach, although for the epidemic of 1705, many tenants (based on the 1702 census) were located without difficulty.

The cross-linking of spatialized information with temporal data has shed light on interactions that had remained invisible when using the traditional tools of historical demography. Applied to a little-known epidemic, this new approach has challenged the diagnoses previously suggested by historians and demographers. The study has also shown the valuable contribution that can be made by geographic information systems to research of this kind. Although the creation of thematic maps is just one among many functions of GIS, the results are much better than those obtained using traditional mapping techniques. Without the combination of both spatial and temporal dimensions, it would have been very difficult to question the earlier diagnoses of smallpox or dysentery previously put forward to explain this selectively lethal epidemic.

This study must now be extended to the city as a whole (work ongoing) — and, if the data so permit, to neighbouring municipalities - in order to confirm our initial findings. Beyond its cartographic capabilities, GIS can also 
be used for spatial and statistical analyses that we will implement on the scale of the three parishes of the city of Martigues. Lastly, the epidemiological study will be extended to include socioeconomic data that were not considered in the present study.

Over the long term, the methodological bases of this study may prove useful for detecting other outbreaks of this same disease, or to identify other infectious agents.

\section{Acknowledgements}

We would like to thank Docteur Yves Darton (CEPAM), for his significant contribution to the debate and diagnosis of this epidemic. Our thanks also extend to Corinne Nicolas-Cabane, for her help with English version, and to Catriona Dutreuilh for the revision of this text. We are grateful to the reviewers for their comments and suggestions which improved the initial version.

\section{References}

Albou, P. 1995. La variole avant Jenner (XVIIe-XVIIIe siècles). Histoire des Sciences médicales XXIX (3): 227-235.

Berman, S. 1991. Epidemiology of acute respiratory infections in children in developing countries. Review of Infectious Diseases 13:S545-S562.

Biraben, J-N. 1975. Les hommes et la peste en France et dans les pays européens et méditerranéens. 2 vols. Paris: La Haye, Mouton.

Bouchut, E. 1873. Histoire de la médecine et des doctrines médicales. Tome 1. Paris: Librairie Germer Baillière.

Burstrom, B., F. Diderichsen, and L. Smedman. 1999. Child mortality in Stockholm during 1885-1910: The impact of household size and number of children in the family on the risk of death from measles. American Journal of Epidemiology 149(12):1134-1141.

Cherry, J.D. 2003. The past, present, and future of pertussis: The role of adults in epidemiology and future control (Specialty Conference). Western Journal of Medicine 150:319-328.

Darmon, P. 1985. La longue traque de la variole: les pionniers de la médecine préventive. Paris: Librairie Académique Perrin.

Desjardins, B. 1996. Demographic aspects of the 1702-1703 smallpox epidemic in the St-Lawrence valley. Canadian Studies in Population 23(1):49-67.

Duncan, S.R., S. Scott, and C.J. Duncan. 1993. The dynamics of smallpox epidemics in Britain, 1550-1800. Demography 30:405-424.

. 1994. Smallpox epidemics in cities in the 17th and 18th centuries. Journal of Interdisciplinary History 25(2):255-271.

—. 1997. The dynamics of measles epidemics. Theoretical Population Biology 52:155-163.

. 1996. Whooping cough epidemics in London 1701-1812: Infection dynamics, seasonal forcing and malnutrional effects. Proceedings of the Royal Society of Britain 263:445-450.

1998. The effects of population density and malnutrition on the dynamics of whooping cough. Epidemiology and Infection 121:325-334.

. 1999. A demographic model of measles epidemics. Revue européenne de démographie/ European Journal of Population 15(2):185-198.

Duvillard de Durand, E-É. 1802. Analyse et tableaux de l'influence de la petite vérole sur la mortalité à chaque âge, et de celle qu'un préservatif tel que la vaccine peut avoir sur la population et la longévité. Paris: Impr. impériale.

Ekamper, P. 2010. Using cadastral maps in historical demographic research: Some examples from the Netherlands. History of the Family 15:1-12. 
Eyler, J. 2003. Smallpox in history: The birth, death, and impact of a dread disease. Journal of Laboratory and Clinical Medicine 142:216-220.

Garenne, M. 1994. Sex differences in measles mortality: A world review. International Journal of Epidemiology 12:632_ 642.

Goualde, N. 2006. Comprendre les épidémies. La coévolution des microbes et des hommes. Paris: Seuil (Les empêcheurs de tourner en rond).

Goubert, P. 1960. Beauvais et le Beawvaisis de 1600 à 1730, contribution à l'histoire sociale de la France du XVIIème siècle. Paris: S.EV.P.E.N.

Gregory, I.N. 2003. A Place in History: A Guide to Using GIS in Historical Research. Oxford: Oxbow.

—. 2005. The Great Britain GIS. Historical Geography 33:132-134.

2008. Different places, different stories: Infant mortality decline in England and Wales, 1851-1911. Annals of the Association of American Geographers 98(4):773-794.

Gregory, I.N., and P.S. Ell. 2005. Analyzing spatiotemporal change by use of National historical geographical information systems: Population change during and after the Great Irish Famine. Historical Methods 38(4):149_ 167.

Guiso, N. 2007. L'impact de la vaccination sur l'épidémiologie des maladies infectieuses: Exemple de la coqueluche. Medecine/Science 23:399-403.

Guiso, N., and F. Simondon. 2001. Épidémiologie de la coqueluche dans le monde. Médecine et Maladies Infectieuses 31(1):5-11.

Knowles, A.K. 2000. Historical GIS: The spatial turn in Social Science History. Social Science History 24:451-470. . 2005. Emerging trends in historical GIS. Historical Geography 33:132-134.

Lebrun, F. 1971. Les hommes et la mort en Anjou aux XVIIème et XVIIIème siècles: Essai de démographie et de psychologie historiques. Paris: La Haye, Mouton.

Le Roy Ladurie, E. 2004. Histoire bumaine et comparée du climat. Tome 1: Canicules et glaciers, XIIIe-XVIIIe siècles. Paris: Fayard.

Mazan, R. 2011. Analyzing Epidemics in New France: The Measles Epidemic of 1714-1715. PhD diss. University of Western Ontario (London, ON).

Mazan, R., A. Gagnon, and B. Desjardins. 2009. The measles epidemic of 1714-1715 in New France. Canadian Studies in Population 36(3-4):295-323.

Neilsen, N.M., K. Hedegaard, and P. Aaby. 2001. Intensity of exposure and severity of Whooping Cough. Journal of Infection 43:177-181.

Oldstone, M.B.A. 1998. Viruses, Plagues, and History. Oxford: Oxford University Press.

Orford, S., D. Dorling, R. Mitchell, M. Shaw, and G.D. Smith. 2002. Life and death of people of London: a historical GIS of Charles Booth's inquiry. Health and Place 8:25-35.

Paoli, J-M. 1971. Martigues an XVIIIème siècle: Un déclin. Mémoire de Maitrise, Université de Provence, Aix-enProvence.

Perrenoud, A. 1979. La Population de Genève du seizième au début du dix-nenvième siècles: étude démographique. Tome 1, Structures et mowvements. Geneva: A. Jullien; Paris: H. Champion (Mémoires et documents publiés par la Société d'histoire et d'archéologie de Genève 47).

Razzell, P. 1977. The Conquest of Smallpox: The Impact of Inoculation on Smallpox Mortality in Eighteenth-Century Britain. Firle: Caliban Books.

Razzell, P. 2007. Population and Disease: Transforming English Society, 1550-1850. London: Caliban. 
Scott, S., and C.J. Duncan. 2001. The Biology of Plagues: Evidence From Historical Populations. Cambridge: Cambridge University Press.

Séguy, I., N. Bernigaud, S. Tzortzis, J-N. Biraben, A. Bringé, G. Davtian, and M. Signoli. 2005a. La diffusion spatiotemporelle d'une épidémie de peste en Basse-Provence au XVIIIe siècle, in Temps et Espaces de l'Homme en société, analyses et modèles spatiaux en archéologie (actes des rencontres Internationales d'Antibes, 21-23 octobre 2004), edited by J-F. Berger, F. Bertoncello, F. Braemer, G. Davtian, and M. Gazenbeek. Antibes: Editions APDCA, pp. 171-174.

Séguy, I., N. Bernigaud, S. Tzortzis, and M. Signoli. 2005b. Towards a GIS for the Study of Past Epidemics: The Example of the City of Martigues (France, in the First Quarter of the XVIIIth Century). Paper presented at the Congrès de la Commission Internationale de Démographie Historique, Sydney (July).

Séguy, I., S. Tzortzis, and M. Signoli. 2007. Caractérisation des crises démographiques en Basse-Provence (16501730), in Peste: entre Épidémies et Sociétés. Plague: Epidemics and Societies, edited by M. Signoli, D. Chevé, P. Adalian, G. Boëtsch, and O. Dutour. Atti 28. Florence: Firenze University Press, pp. 197-204.

Signoli, M., I. Séguy, J.-N. Biraben, and O. Dutour. 2002. Paleodemography and historical demography in the context of an epidemic: Plague in Provence in the eighteenth century. Population 57(6):829-854.

Sköld, P. 1996a. From inoculation to vaccination: Smallpox in Sweden in the eighteenth and nineteenth centuries. Population Studies 50(2):247-262.

- 1996b. The Two Faces of Smallpox: A Disease and its Prevention in Eighteenth-and Nineteenth-century Sweden. Umea: Demographic Data Base, Umea University.

Shulman, S.T. 2004. The history of pediatric infectious diseases. Pediatric Research 55(1):163-176.

Tissot-Dupont, H. 2009. Climat, environnement et infections respiratoires. Médecine et maladies infectieuses 39:200-202.

Tuckel, P., S. Sassler, R. Maisel, and A. Leykam. 2006. The diffusion of the influenza pandemic of 1918 in Hartford, Connecticut. Social Science History 30(2):167-196.

WHO. 1999. Systèmes d'information géographique (SIG). Relevé épidémiologique hebdomadaire 34:281-285.

WHO website. http://www.who.int/topics/smallpox/en/; http://www.who.int/topics/pertussis/en/; http:// www.who.int/topics/measles/en/

Yu, H-L., and G. Christakos. 2006. Spatiotemporal modelling and mapping of the bubonic plague epidemic in India. International Journal of Health Geographics 5:12. 
